Astrid Męczkowska-Christiansen

ORCID: 0000-0002-4966-7856

Akademia Marynarki Wojennej w Gdyni

a.meczkowska-christiansen@amw.gdynia.pl

\title{
Pulsujące metafory dydaktyki w kleszczach języka. O lingwistycznych blokadach konstruktywistycznej zmiany w kształceniu
}

\section{Summary \\ Pulsating metaphors of didactics in the tongs of the tongue. \\ On the linguistic blockades of constructivist change in education}

The content of the article includes analyses of the linguistic plane of the reception of constructivist didactics, carried out in order to seek a partial answer to the question: why does the paradigmatic change in the area of school education in Poland, which has been intensively postulated by scientific circles over the last thirty years, not materialise in the space of contemporary educational practices in their institutional settings? In particular, the subject of analyses refers to the dominant - "instructive" - linguistic level of general didactics, with regard to such concepts as: education, learning, knowledge. The purpose of the linguistic analyses was to show how the existing constellations of didactic metaphors have hindered the conceptualisation and reception of ideas coming from constructivist positions.

Keywords: constructivist didactics, instructional didactics, knowledge/knowing, learning, education, linguistic analysis, linguistic metaphor

Slowa kluczowe: dydaktyka konstruktywistyczna, dydaktyka instruktywistyczna, wiedza, uczenie się, edukacja, analizy lingwistyczne, metafora językowa

Wielości paradygmatycznych ujęć procesu kształcenia, obecnych w różnorodnych nurtach współczesnej teorii i praktyki dydaktycznej, towarzyszy (re)konstrukcja jej kluczowych pojęć, pełniących funkcje lingwistycznie rozumianych metafor. Tak postawiona teza pośrednio znajduje odniesienie do szkicowanej przez Joannę Rutkowiak (1995a, b) mapy „pulsujących kategorii pedagogicznych” jako strukturotwórczych, polisemicznych pojęć o wysokim stopniu ogólności, stanowiących osnowę dla budowania rozległych konstrukcji teoretycznych (zob. Skarga 1989: 105). Zdaniem Rutkowiak obecność pulsujących kategorii jest pochodną empirii edukacyjnej, jej napiętych pól i wyłaniających się z nich „Szczególnie żywych” znaczeń (Rutkowiak 1995b: 184). O ile można rozumieć pulsujące kategorie w terminach lingwistycznych, o tyle ich semantyczna treść będzie wtórna wobec 
społecznej praxis. W odwołaniu do podstawowego dla przedstawianych analiz pojęcia „pulsujących metafor” zakładam drogę odwrotną - posługując się tą kategorią, analizuję zjawiska leżące po stronie języka, w założeniu konstytutywne dla pola praxis. Stawiam zatem w nawiązaniu do drogi, jaką rozważania lingwistyczne przebyły przez co najmniej ostatnie półwiecze, tezę o pierwotności języka i wyrażanych w nim znaczeń do konstruowania dydaktycznych dyskursów, równolegle obejmujących teorię i praktykę. Teza ta ma charakter stricte narzędziowy. Nie chodzi mi o jej nadmierne rozwijanie lub umacnianie; stawką nie jest także polemika z odmiennymi stanowiskami. Celem jest raczej ukazanie, w jaki sposób konstelacje metafor, tworzących swoiste „mitologie” uwikłane w język dydaktyki, stają się blokadą (przynajmniej jedną z wielu) realizacji paradygmatycznej zmiany w obszarze praktyk kształcenia realizowanych przez polską szkołę, desperacko przywiązaną do instrumentalno-behawioralnych wzorców dydaktycznych. W tym sensie kieruję uwagę ku grawitacyjnej sile oddziaływania języka dydaktyki ,instruktywistycznej”, głęboko zakorzenionego w rodzimej kulturze pedagogicznej, która daje skuteczny odpór ideom płynącym ze strony stanowisk konstruktywistycznych.

Nawiązując do myśli wyrażonej we wczesnej pracy Wittgensteina: ,[g]ranice mojego języka oznaczają granice mojego świata" (2002: 64), można rzec, że pojęciowe kontury naszego myślenia wyrażanego w języku stanowią reprezentację rzeczywistości jako ,jedynej do pomyślenia”, a zarazem „wypowiedzenia”. Refleksy tej myśli są wyraźnie obecne w przestrzeni analiz współczesnej lingwistyki kognitywnej, gdzie dokonuje się badania relacji pomiędzy lingwistycznymi a pojęciowymi reprezentacjami rzeczywistości (Langacker 1987; Talmy 2000; Langacker 2002). Przywołaną perspektywę można odnieść także do innych tradycji analiz lingwistycznych lub z nimi związanych, takich jak Foucaultowskich i postfoucaltowskich podejść osadzonych w ramach analiz dyskursu, a także do tradycji heremenutyczno-lingwistycznej w ujęciu Hansa Gadamera i jego następców. To, co pomyślane/konceptualizowane, kreuje pole społecznych praktyk - pokazuje Michel Foucault; dyskurs ,powołuje jego obiekty” (Foucault 1972: 49). Ci, którzy zostali wychowani w określonej tradycji językowej, postrzegają rzeczywistość w sposób przez nią „językowo ukonstytuowany" - twierdzi Gadamer, choć jednocześnie wykazuje względną otwartość tak konstruowanych obrazów świata na wejrzenie „z zewnątrz” (2004: 601). Teza o obecności odrębnych systemów językowych, dostarczających podstaw do tworzenia jakościowo zróżnicowanych reprezentacji rzeczywistości, jest uzasadniana także przez wcześniejszych badaczy: znajdujemy ją w stanowisku aprioryzmu lingwistycznego Alexandra von Humboldta, w hipotezie determinizmu językowego Edwarda Sapira i Benjamina Whorfa czy w koncepcji ,językowego obrazu świata" $u$ Leo Weisgerbera (Andrzejewski 1983, 1986; Wendland 2011: 93-121). Pomimo że teza ta przyjmowała niekiedy charakter dogmatyczny, jej recepcja, przy spełnieniu warunku kantowskiego krytycyzmu, stanowi punkt wyjścia dla analiz współczesnego konstruktywizmu komunikacyjnego (zob. Wendland 2011: 121 i nn.).

Systemy językowe otoczone są granicami. Oddzielają one tożsame od innego, wyobrażalne od niewyobrażonego, postrzegane od niedostrzegalnego. Funkcją owych granic 
staje się „dzielenie postrzegalnego”, stanowiące akt interwencji w to, co można zobaczyć i powiedzieć - twierdzi Jacques Rancière (2007) - i jako takie jest ono domeną polityki, na wskroś przenikającej każdy aspekt społecznej praxis. „Dzielenie postrzegalnego” jako „dzielenie” wypowiedzianego i pomyślanego zarazem - stanowi odwieczną domenę filozofii, która ma za zadanie „wytyczać granice tego, co da się pomyśleć, a tym samym i tego, co się pomyśleć nie da” (Wittgenstein 2002: 28). „Dzielenie postrzegalnego” jest także funkcją nauki - zadomawiających się w niej dyskursów jako pewnych form ,performatywnych opowieści” o przedmiotach jej poznania (Foucault 2006; Błesznowski 2016), a zarazem paradygmatów, przez pryzmat których patrzymy na zjawiska, wyznaczających ich dostrzegalne ( $\mathrm{z}$,wnętrza” paradygmatu) kształty. Przywoływane tu pojęcie „paradygmat” ma proweniencje Platońskie; odnosi się do - opisywanych w dialogu Timajos - paradeigmata jako wzorców kosmicznej konstelacji wszechświata, czystej formy wykorzystanej przez demiurga do jego stworzenia. Jest to model wieczny i niezmienny (Grabowski WWW). W odniesieniu do nauki (pominąwszy, chwilowo, doniosłe w tej kwestii stanowisko Thomasa Kuhna) platońsko pomyślany paradygmat odnosi się do cech formy, nie zaś samej treści. To nie teoria lub teorie naukowe powszechnie uznawane w jakimś czasie i miejscu przez środowisko uczonych (Kuhn 2001) wyznaczają ów platońsko pomyślany paradygmat, lecz ich forma, którą można uznać za strażnika treści. Tak pojęte paradygmaty mają moc „wytwarzania nowego kontekstu ontologicznego” (Agamben 2002: 18). W odniesieniu do sposobów uprawniania dydaktyki jako po Foucaultowsku rozumianej dyscypliny - a zatem nie tylko dyscypliny naukowej, lecz całego repertuaru narzędzi regulujących praktyki społeczne: poznawczych (usankcjonowana teoria), instytucjonalnych etc., przekładających się na jedność wiedzy i władzy - paradygmaty nie tyko wytwarzają dyskursy jako pojęciowo-językowe ramy do powoływania swoich obiektów, ale także stanowią przestrzenie generowania pewnych mechanizmów/metod sprawowania władzy, wnikając zarówno w przestrzeń tradycyjnie pomyślanych dyscyplin naukowych, jak i praktyk kulturowych (zob. Klus-Stańska 2019: 19 i nn.). W tym sensie odmienność języków dydaktyki można odczytać jako obrazującą konflikt pomiędzy dyskursami władzy-wiedzy; dyskursami, które nie tylko ustalają, „czym jest rzeczywistość nauczania i uczenia się" (Klus-Stańska 2010: 146), ale także sprawują kontrolę nad podmiotami tej rzeczywistości: uczniami i nauczycielami, wkraczając w sferę konstytuowania ich podmiotowości, regulując sferę ich autonomii i wyposażając w określone techniki podporządkowania bądź uczestnictwa w sprawowaniu władzy.

Podkreślę ponownie moje rozumienie paradygmatu w kategoriach formalnych: niezależnie od ich treściowego ujęcia (zob. Klus-Stańska 2019: 42 i nn.) paradygmaty można odnieść do zaplecza językowego dydaktyki lub raczej - dydaktyk, o ile nawiązywać będziemy do ich generycznej odmienności, wskazywanej przez Dorotę Klus-Stańską (2019). Wychodząc od tego znaczenia i wskazując, za Giorgio Agambenem, ontologiczną wytwórczość paradygmatów - języki dydaktyk uznać należałoby za pierwotne w stosunku do treści. Warto, jak sądzę, wziąć to pod uwagę, zastanawiając się nad kwestią, która od dłuższego czasu angażuje moje myślenie (wielokrotnie zastanawia ona także 
moich studentów): dlaczego zmiana paradygmatyczna w obszarze kształcenia szkolnego w Polsce, intensywnie postulowana przez środowiska naukowe w ciągu ostatniego trzydziestolecia, ,powierzchniowo" postulowana na poziomie oficjalnych podstaw programowych kształcenia ogólnego, entuzjastycznie (częściowo - w sferze deklaracji) wyczekiwana przez nauczycieli, nie ulega materializacji w przestrzeni społecznych praktyk funkcjonowania szkoły? Odpowiedzi, przynajmniej prowizorycznej, na tę kwestię upatruję w analizie języka dominującego paradygmatu dydaktyki w jego instrumentalno-behawioralnej odsłonie. Wyrażam przy tym przekonanie, że zmiana w kształceniu wymagałaby dokonywania przekształceń na elementarnym poziomie języka jako klucza do transformacji pojęć fundujących konceptualizację i realizację określonych praktyk kształcenia. Nie chodzi tu jedynie o zmianę języka dydaktyki akademickiej - alternatywne (wobec nurtu obiektywistyczno-behawioralnego) typy dyskursu są w niej dobrze zadomowione; zwłaszcza w ich konstruktywistycznych odmianach. Zmiana języka powinna dotyczyć dydaktyki jako Focaultowsko pojmowanej dyscypliny: wraz z jej teorią i praktyką, jej kontekstami potocznymi, wyrażanymi w pop-dydaktyce, folk-dydaktyce (Klus-Stańska 2010: 72-95), a w końcu - na elementarnym poziomie pojęć naszego rodzimego języka, w którym pewne - konstruktywistycznie rozumiane - pojęcia fundujące ideę kształcenia są nie do pomyślenia i trudne do wyrażenia w języku innym niż wyrafinowany język akademicki.

Odnosząc się do zmiany pojęć ujętych w języku (jako tworzywa, a zarazem formy dydaktycznych dyskursów), szukam uzasadnień swoich zabiegów w domenie kognitywno-lingwistycznych ujęć, obecnych w obszarze krytycznej analizy dyskursu (Hart 2011, 2013). W tej perspektywie mówimy nie tyle o izolowanych pojęciach, ile o ich kontekstualnie osadzonych wariantach, pełniących funkcję metafor. Metafora jest tu uznawana za reprezentację mentalną, stanowiącą podstawowe narzędzie ludzkiego myślenia. Jest rozpatrywana głównie jako forma tworzenia relacji między obiektami lub domenami pojęciowymi. Jest także uznawana za podstawowe narzędzie ludzkiego myślenia (Filar 2017). Metafora jest czymś głębszym niż same pojęcia - jest traktowana jako podstawa wytwarzania pojęć, jako charakterystyczny dla intelektualnej działalności człowieka typ reprezentacji umysłowej oraz jako naturalny sposób konceptualizacji doświadczeń, a zarazem sposób strukturalizacji wiedzy (Filar 2017).

Szczególne znaczenie metafor dla dydaktyki odnosi się do konceptualizowanej w jej ramach relacji pomiędzy takimi „obiektami” jej dyskursu, jak: kształcenie, nauczanie, uczenie się i wiedza. Właściwy przedmiot moich analiz stanowi dyskurs instrumentalno-behawioralny w dydaktyce, który - roboczo - za anglojęzycznymi źródłami zarówno naukowymi, jak i folk-dydaktycznymi - oznaczę, korzystając z określenia ,instruktywizm”. Zdaję sobie sprawę, że wykorzystuję tu pewną metaforykę, polegającą na (raczej binarnym) przeciwstawieniu sobie dwóch dyskursów dydaktycznych: obiektywistyczno-instrumentalnego, zakorzenionego w ideologii transmisji kulturowej (Kohlberg, Mayer 1993) i najsilniej współcześnie reprezentowanego przez dydaktykę behawioralną, oraz konstruktywistycznego, wraz z jego różnymi wariantami. Warto podkreślić, że celowo 
zrezygnowałam ze sporów o klasyfikacje dydaktycznych nurtów i paradygmatów; nie podjęłam się analizy ich genealogii i wzajemnych związków.

Instruktywistyczna metafora kształcenia nadaje mu charakter obiektywny, rozumiany w kategoriach prowadzenia do zbieżności z wzorcami osobowymi lub spełniania kryterium normy (te dwa obszary nie stanowią kategorii rozłącznych). Takie rozumienie ukształtowało się w domenach rozmaitych nurtów/dyskursów dydaktycznych: w niektórych systemach (herbartyzm, dydaktyka szkoły socjalistycznej) odnosiło się ono głównie do dążenia do sprostania kryteriom ideału wychowania, czyli wzorca osobowego traktowanego jako sposób artykulacji nadrzędnych celów wychowania. W innych odmianach (neoliberalny dyskurs społeczeństwa wiedzy lub dydaktyczny behawioryzm) siła ciężkości oddziaływań koncentrowała się wokół normatywnych kryteriów wypełniania pożądanych ról społecznych, z naciskiem na kształtowanie określonych atrybutów zachowaniowych lub kompetencyjnych. Kształcenie jako proces obiektywny ma charakter dokonany, sygnalizujący, że jego efektem końcowym jest ostateczne „wykształcenie”, uformowanie jego uczestników. Rezultaty wykształcenia są wymierne, tj. mierzalne, dające się opisać w postaci ilościowo określonych parametrów. Jeden ze świeższych w tym zakresie przykładów mogą stanowić Polska Rama Kwalifikacji lub Europejskie Ramy Kwalifikacji, artykułowane w obszarze neoliberalnego dyskursu społeczeństwa wiedzy. (Dodam, że traktuję ten dyskurs jako dydaktyczny, choć tworzony poza ramami dydaktyki jako subdyscypliny pedagogicznej).

Kształcenie jest rozumiane w oderwaniu od wychowania i rozwoju struktur psychicznych. Parafrazując Wygotskiego, polemizującego z „wczesnym” Piagetem, „kształcenie wlecze się za rozwojem" (Wygotski 1971: 543) w tym sensie, że jego warunkiem jest „ukształcalność" (określenie m.in. herbartystów) jego podmiotu, rozumiana w kategoriach podatności na recepcję treści dostosowanych do apriorycznie ustalanej normy. W tym sensie sam program kształcenia pełni funkcję normalizującą. Można tu zastosować metaforę kształcenia jako wypełniania pojemnika: o ile rozwój ucznia dostarcza „,chłonnego umysłu" jako pojemnika na treści kształcenia i prowadzi do stopniowego zwiększania jego objętości, o tyle kształcenie polega na systematycznym wypełnianiu go treścią. W tym znaczeniu metafora „kształcenia” przyjmuje charakter bliski pojęciu „,nauczanie”, rozumianemu jako transfer wiedzy i wyrażanemu w powszechnej, zdroworozsądkowej metaforze „szkoły, która przekazuje wiedzę”. Takiemu rozumieniu kształcenia towarzyszy traktowanie go jako rozłącznego wobec procesu wychowania. Pedagogika naukowa, a w jej ramach instrumentalna dydaktyka szkoły socjalistycznej umocniły przekonanie, że kształcenie dotyczy oddziaływań adresowanych do sfery poznawczej, wychowanie zaś emocjonalno-wolitywnej. Jak twierdzi Joanna Rutkowiak, rozwijająca się od przełomu XIX i XX w. pedagogika naukowa występuje ,z zamiarami ustanawiania i realizowania człowieka o określonej jakości, podzielonego, jak w mechanice, na poszczególne cechy i właściwości, wśród których gubi się on jako całość" (1992: 25).

Instruktywistyczna metafora kształcenia obejmuje przekonanie o koniecznej zależności pomiędzy kształceniem a jego instytucjonalizacją; przypisywaną mu cechą jest „,przeregulowanie” aktywności kształconych za sprawą tych warunków. Jest ono zatem zawsze 
sterowane zewnętrznie i utożsamiane z jego formalną postacią. Zwróćmy także uwagę na obecność sygnalizującej to - zastanej - konwencji językowej: „kształcić się” to uczestniczyć w kształceniu formalnym, nie zaś nieformalne „uczyć się”.

Opisana przeze mnie metaforyka kształcenia jest reprezentowana nie tylko w dydaktyce, lecz i w codziennej konwencji językowej, znajdując odbicie w treści popularnych słowników i encyklopedii. Na przykład według Encyklopedii PWN kształcenie to „ogół czynności i procesów mających na celu przekazywanie wiedzy, kształtowanie określonych cech i umiejętności”, zgodnie z definicją słownikową zaś pojęcie „kształcenie” odnosi się w głównej mierze do przekazywania komuś wiedzy (Słownik języka polskiego PWN). $\mathrm{Z}$ tego powodu zakorzeniona w rodzimej tradycji językowej (a także mentalnej) metafora kształcenia utrudnia jego rozumienie w perspektywie dydaktyki konstruktywistycznej, związanej z angażowaniem wysiłku myślenia - w różnych jego odmianach (logicznego, problemowego, krytycznego, twórczego etc.) bez względu na jego instytucjonalny/pozainstytucjonalny kontekst oraz na jego powiązania z kwestią kierowania procesem uczenia się. Utrudnia ona także rozumienie kształcenia jako synonimu wychowania, co także - ze względu na zakładaną w obszarze konstruktywizmu/konstruktywizmów głęboką interakcję różnorakich sfer rozwoju - nie pozwala na separowanie „kształcenia” i ,wychowania”. Kuszące wydaje mi się postawienie hipotezy, że idee konstruktywistyczne w dydaktyce nie mogłyby wyrosnąć na podłożu rodzimej konwencji językowej. Education jako anglojęzyczny odpowiednik pojęcia „kształcenie”, źródłowy dla efektywnej popularyzacji idei konstruktywistycznych w polu praktyk dydaktycznych na świecie, ma ogromną pojemność znaczeniową, łącząc w sobie pojęcia kształcenia i wychowania, ich instytucjonalne i pozainstytucjonalne konteksty oraz integrując je z problematyką rozwoju. Education do dziś zachowuje łaciński - podwójny - rdzeń znaczeniowy: educere lub dūcō (rozwijam się, wznoszę, wzrastam) oraz educare (przewodzę, prowadzę) (Craft 1984). Odnosząc się do specyfiki rodzimego języka - przerwanie ciągłości pojęcia „kształcenie/wychowanie” wydaje się kluczową barierą dla możliwości myślenia o tym procesie w kategoriach konstruktywistycznych.

Uczenie się jest popularnie rozumiane jako „przyswajanie wiedzy” - czynności tej przypisuje się charakter reaktywny, wymuszony. Jest odpowiedzią na wymagania dydaktyczne. Takie rozumienie uczenia się doskonale koresponduje z Watsonowskim modelem człowieka jako „czarnej skrzynki”, a zatem zewnątrzsterownego obiektu, przetwarzającego bodźce na zachowania. Uczenie się jest tu jedynie realizowanym przez ucznia przedłużeniem roli nauczyciela, polegającej na ,napełnianiu pustego pojemnika”. Przypisuje się mu także charakter adaptacyjny. Podobnie jak - w obszarze wczesnego behawioryzmu psychologicznego - uczenie się organizmów opisywano jako zmianę zachowań o charakterze adaptacyjnym wobec oddziałujących bodźców, tak uczenie się w klasie szkolnej stanowi wynik adaptacji do sytuacji „bodźcowania” - tym razem za pośrednictwem wymagań dydaktycznych stawianych przez nauczyciela (i idących za nimi sankcji). W opozycji do konstruktywistycznie pojmowanego ,,uczenia się” jego ,,instruktywistyczny” odpowiednik obejmuje także tryb dokonany. Oznacza to, że można się „nauczyć”/ 
„wyuczyć”. Cytując za polskojęzyczną Wikipedią: „[e]fektem uczenia się jest nabycie określonej wiedzy lub umiejętności”. Podobnie brzmią definicje słownikowe (Stownik języka polskiego $P W N$ ). Polskojęzyczne konteksty pojęcia „uczyć się” obecne w mediach w odniesieniu do działalności szkoły (programy informacyjne i publicystyczne w telewizji, popularne źródła internetowe) obejmują rozumienie uczenia się niemal wyłącznie w kategoriach „uczenia się po śladzie” (Bruner 1996), przy czym nauczanie jest tu traktowane jako źródło lub konieczny impuls do zainicjowania procesu uczenia się. Zakleszczenie metaforyki uczenia się w kategoriach „instruktywistycznych”, charakterystyczne dla świadomości potocznej i przekazywane wraz z pierwotną konwencją językową, stanowi blokadę na drodze nadawania konstruktywistycznych znaczeń pojęciu uczenia się jako aktywności poznawczej motywowanej wewnętrznie i zorientowanej na (re)konstruowanie istniejących typów reprezentacji poznawczych, a ponadto jako naturalnej, niewymuszonej, przyrodzonej gatunkowi ludzkiemu formy bycia w świecie. Warto zauważyć - obecna w „instruktuwizmie” metaforyka uczenia się jako „wymuszonego” w ogóle nie jest obecna w konstruktywizmie. Co ciekawe, w metaforyce konstruktywistycznej nie występuje także - kluczowe dla rodzimej dydaktyki instrumentalno-behawioralnej - pojęcie „wymagań dydaktycznych” (w zamian operuje się pojęciami: „wyzwania, zadania i aktywność ucznia”). „Instruktywistyczna” metaforyka wyklucza także ze swojej domeny rozumienie uczenia się w kategoriach aktywności społecznie podzielanej i występującej w nieustającej interakcji z kulturą, dostarczającej skrzynki z narzędziami rozwijającym się umysłom (Bruner 1996: x-xi).

W obszarze metaforyki instruktywistycznej nauczanie jest odnoszone do skutecznej transmisji treści kształcenia, rozumianej w kategoriach materializmu dydaktycznego. W szczególności mamy tu do czynienia z metaforą „przekazu wiedzy” jako zestawu informacji ,gotowych do przyswojenia”, cechującego się sztywną strukturą. Ponadto w świadomości potocznej, ale także w świadomości dydaktycznej nauczycieli nauczanie bywa sprowadzane do „realizacji programu nauczania” jako spełniania formalnych, biurokratycznie pojmowanych zadań, wynikających z roli zawodowej nauczyciela oraz instytucjonalnego kontekstu kształcenia. Taka konceptualizacja wyklucza rozumienie nauczania w terminach „facylitacji” jako pobudzania uczącego się umysłu do aktywności konstruowania wiedzy, której rdzeń stanowi negocjacja znaczeń publicznych i osobistych. Metafora nauczyciela, jako pochodna metafory nauczania, przyjmuje technologiczne konotacje, doskonale uwidaczniające się w behawioralnie zorientowanej dydaktyce. W domenie konstruktywistycznie zorientowanego piśmiennictwa anglojęzycznego pojęcia „nauczyciel” i „nauczanie” przeważnie bywają wyrażane w terminach „facylitator” i „facylitacja”. Pytaniem pozostaje, dlaczego ta konwencja nie znajduje odzwierciedlenia w źródłach polskojęzycznych.

„Instruktywistyczna” metafora nauczania w pewien sposób konstruuje także metaforę ucznia. W instruktywistycznej konstelacji znaczeń uczeń nie jest podmiotem uczenia się, lecz obiektem nauczania. W anglojęzycznej konwencji językowej związanej z konstruktywizmem słowo „uczeń” (pupil) zostało wymazane z języka dydaktyki. Wbrew 
tradycyjnym konwencjom (głównie amerykańskiej i brytyjskiej, wciąż sygnalizowanych w anglojęzycznych słownikach) pojęcia student używa się tu także w odniesieniu do najmłodszych uczestników edukacji, podkreślając ich aktywną rolę jako podmiotów konstruujących wiedzę - a zatem „studiujących”. W języku rodzimym ta konwencja byłaby raczej trudna do przyjęcia, lecz jej oswojenie w ramach - najpierw dydaktycznej, a następnie potocznej świadomości - mogłoby doprowadzić do stopniowych zmian w powszechnym postrzeganiu poznawczej aktywności uczniów.

Instruktywistyczna metafora wiedzy sprowadza ją do zbioru elementów określanych jako ,informacje” (w dyskursie społeczeństwa wiedzy) bądź ,wiadomości” (w obszarze polskojęzycznych wydawnictw popularyzujących nurt dydaktyki behawioralnej). Elementy składające się na „wiedzę” są policzalne - dlatego można mierzyć „przyrost wiedzy”. Uwidaczniająca się w tej perspektywie atomizacja wiedzy znajduje uprawomocnienie w postaci oficjalnych ponadnarodowych wykładni regulujących polityki oświatowe państw Unii Europejskiej, wchodzących w zakres oficjalnego dyskursu społeczeństwa wiedzy (lub - aktualnie - gospodarki opartej na wiedzy (Męczkowska-Christiansen 2014)). $\mathrm{W}$ dyskursie tym mamy także do czynienia z rozumieniem wiedzy w kategoriach utylitarystycznych (zob. Skrzypek 2007), ponieważ wprost przypisuje się jej postać aktywów, czyli dóbr ekonomicznych, jej depozytariuszom zaś - „elementów” kapitału ludzkiego. Wiedzy przypisuje się postać zasobu oddzielonego od świadomości podmiotów. W tym sensie można mówić o alienacji wiedzy od ludzkiego umysłu, człowiek jest tu bowiem postrzegany nie tyle jako podmiot wiedzy (czyli ten, który „wie”, „rozumie” oraz dokonuje operacjonalizacji wiedzy w procesie działania), ile jej ewentualny depozytariusz lub wprost - ,aplikator”. Jego rola polega na „nabywaniu naukowej i technicznej wiedzy ze źródeł zewnętrznych" (OECD 2004: 8) oraz jej aplikowaniu w obszarze gospodarki. Zarówno w perspektywie dydaktycznej (dydaktyka behawioralna), jak i w perspektywie neoliberalnego manageryzmu oświatowego (Męczkowska-Christiansen 2015) wprowadza się technokratyczne, absurdalne - w odniesieniu do kognitywistycznego rozumienia wiedzy klasyfikacje dotyczące jej postaci. Jedną z nich może pośrednio dostarczyć „klasyczna” już taksonomia ABC Bolesława Niemierki (1991), oparta na deklarowanym przez behawioryzm stanowisku o świadomym ignorowaniu zagadnień dotyczących umysłu i procesów poznawczych (Watson 1913). Taksonomie o podobnie redukcjonistycznym charakterze są dostarczane przez dyskurs społeczeństwa wiedzy (OECD 2000: 14; UNESCO 2005: 60). Mamy tu do czynienia z metaforyką, ,wiedzy bez podmiotu” (Męczkowska-Christiansen 2014), ,produkowanej” w obszarze wyspecjalizowanych centrów, oddzielonej od naturalnej aktywności umysłowej człowieka, a zarazem tworzonej poza dostępną mu kulturą. W domenie ,instruktywizmu” wiedza występuje zatem w roli podwójnie rozumianego produktu: jako efektu uczenia się zorientowanego na jej „opanowanie” (czyli asymilację w świetle instrumentalno-dydaktycznej terminologii) oraz wytworu wyspecjalizowanych centrów produkujących wiedzę i dostarczających jej oficjalnych wykładni m.in. instytucjom edukacyjnym (proces ten, rzecz jasna, jest zapośredniczony przez twórców programów szkolnych, podręczników oraz kanonicznych kompaktów „wiedzy szkolnej”). 
Osadzenie wiedzy w perspektywie łańcucha znaczeń związanych z okołoedukacyjnym „cyklem jej życia”, czyli produkowaniem-obiektywizacją-transmisją-nabywaniemreprodukowaniem-mierzeniem poziomu opanowania, jest wyrażane językowo i przekształcane w system pojęć utrwalających konceptualne schematy „instruktywistycznie” zorientowanej dydaktyki. Zakleszczenie w ich ramach pojęcia „wiedza” powoduje niedostatki (rodzimego) języka, który staje się niezdolny do pełnienia narzędzia artykulacji jej konstruktywistycznie pojmowanych znaczeń. A odnoszą się one głównie do rozumienia wiedzy jako głębokiej reprezentacji poznawczej, aktywnie konstruowanej w interakcji ze światem (społecznym, kulturowym, przyrodniczym), przyjmującej postać konstruktów osobistych występujących także w powiązaniu z osobistymi wymiarami struktury intrapsychicznej oraz cielesnej (Brown i in. 1989; Smith 1999) - w tym sensie metafora wiedzy pochodzącej z ,zewnątrz”, wiedzy, która jest „darem od tych, którzy wiedzą, dla tych, którzy nie wiedzą” (Freire 2000: 70), „wiedzy”, którą można dawkować i połykać jak pastylki etc., jest całkowicie nieprzekładalna na sposoby jej konstruktywistycznego rozumienia, obejmujące także konsekwencje w postaci zakwestionowania naiwnie reprezentacjonistycznej teorii umysłu, zgodnie z którą reprezentacje umysłowe są traktowane jako odzwierciedlające stan świata (Zahorodna 2015: 18).

Polskojęzyczne konotacje pojęcia „wiedza”, denotujące jej charakter jako „zasobu”, nie sprzyjają jej ujmowaniu w terminach procesu konstruowania wiedzy, denotowanych przez słowo knowing, powszechne dla anglojęzycznego piśmiennictwa konstruktywistycznego. Knowing is a process not a product - konstatuje Bruner (1966: 72).

Ograniczenia języka dydaktyki, wynikające - jak starałam się to ukazać - z samych właściwości rodzimego języka, struktury jego pojęć, uwikłanych weń metafor wyrosłych na wielowiekowej „kulturze dydaktycznej”, stanowią blokadę na drodze recepcji konstruktywistycznych idei. Bez zmiany na poziomie języka konstruktywizm w świadomości nauczycieli może przyjmować jedynie oblicza pop-konstruktywistyczne, niesięgające jego warstw ontologicznych (dotyczących relacji między bytem a poznającym umysłem, a także uwzględniających problematykę teorii umysłu) oraz epistemologicznych (dotyczących relacji między poznającym umysłem a wiedzą jako procesem). Powierzchniowe warianty pop-konstruktywizmu są dość wyraźnie obecne w publicznopedagogicznych dyskursach oscylujących wokół problematyki konstruowania wiedzy rozumianego jako „samodzielna praca ucznia”, zastosowanie „metod aktywnych” i ,uznanie podmiotowości” dziecka w procesie uczenia się. Dokonując bardzo pobieżnej analizy pedagogicznych dyskursów konstruktywizmu, publikowanych w źródłach internetowych (artykułach naukowych, wypowiedziach i publikacjach nauczycielskich, a także publikacjach zamieszczanych na stronach placówek oświatowych), dostrzegłam nader wyraźny niedostatek języka/pojęć, w ramach których możliwe jest wyrażenie konstruktywistycznych idei. Oto przykłady, których dostarczyło mi pięciominutowe wykorzystanie wyszukiwarki Google:

Uczeń może z łatwością dokonać asymilacji nowego bodźca, którym może być np. nowa zależność odkryta w wyniku podjętych działań. (publikacja nauczycielska) 
Dla nauczyciela wpisującego się w model konstruktywisty aktywne uczenie się oznacza zrozumienie istoty danego zagadnienia i świadomą nad nim pracę tak długo, aż uczeń zacznie robić to automatycznie. (publikacja akademicka)

Nauczyciel konstruktywista w równym stopniu jest zobowiązany do kształcenia i wychowania, jak i do rozbudzania zainteresowań uczniów i organizowania im warunków do samodzielnego rozliczania się za swoją pracę. (publikacja akademicka)

Konstruktywiści dużą uwagę poświęcają na to, żeby treści, jakie przyswajają dzieci, były różnorodne. Aby zajęcia były ciekawe, należy (...) uruchomić jak najwięcej bodźców. (ze strony internetowej placówki oświatowej)

Trudno mi dokonać podsumowania przedstawionych tu rozważań. W zamian, powracając do pytania o to, dlaczego recepcja idei konstruktywistycznie zorientowanej dydaktyki jest tak problematyczna, zaproponuję kilka postulatów. Przede wszystkim postulowałabym wprowadzenie działań dydaktyków akademickich zorientowanych na uważną weryfikację języka dydaktyki oraz działania na rzecz zmiany konwencji językowej w zakresie stosowania wybranych pojęć (na ile to możliwe). Dostrzegam także konieczność bardziej intensywnego uczestnictwa konstruktywistycznie zorientowanych dydaktyków akademickich w dyskursie publicznym, w tym także - w segmencie rynku wydawniczego adresowanego do rodziców i nauczycieli, oczekujących literatury o charakterze quasi-mentorskim i poradnikowym. Zdaję sobie sprawę z problematyczności wyzwania, które tu formułuję, lecz w dalszym ciągu celem jest „oswajanie” nowego języka dydaktyki w sferze publicznej. W końcu - jakkolwiek banalnie brzmi ta propozycja - uważam, że kształcenie nauczycieli w obszarze dydaktyki wymaga gruntownego zapoznania się z jej językami poprzez m.in. realizację zajęć przypominających seminarium z zakresu lingwistyki porównawczej. Stawką proponowanych działań jest zmiana w zakresie dominującego języka „dydaktyki powszechnej”, pełni on bowiem - co starałam się ukazać - funkcję performatywną; jest to język, który współkonstytuuje rzeczywistość edukacyjną.

\section{Literatura}

Agamben G. (2002), What is a paradigm? http://www.egs.edu/faculty/giorgio-agamben/articles/ what-is-a-paradigm, 21.09.2018.

Andrzejewski B. (1983), Leo Weisgerbera relatywistyczna koncepcja języka. „Studia Metodologiczne", 22.

Andrzejewski B. (1986), Aktywistyczne koncepcje języka a rzeczywistość pozajęzykowa. „Poznańskie Studia z Filozofii Nauki”, 10.

Błesznowski B. (2016), Dyskurs jako praxis. Archeologia wiedzy jako teoria materializmu performatywnego. „Praktyka Teoretyczna”, 22. 
Brown J.S., Collins A., Duguid P. (1989). Situated cognition and the culture of learning. „Educational Researcher", 18(1).

Bruner J. (1996), The Culture of Education. Cambridge, Harvard University Press.

Craft M. (1984), Education for diversity. W: M. Craft (ed.), Education and cultural pluralism. London-Philadelphia, Falmer Press.

Dijk van T.A. (1998), Ideology: A multidisciplinary approach. London, Sage.

Encyklopedia PWN. https://encyklopedia.pwn.pl/haslo/edukacja;3896542.html, 11.11.2020.

Filar M. (2017), Metafory konwencjonalne i nowe $w$ dyskursie migracyjnym - analiza $w$ ramach krytycznej lingwistyki kognitywnej. „Lingwistyka Stosowana”, 21(1).

Foucault M. (1972), The archaeology of knowledge. New York, Pantheon Books.

Foucault M. (2006), Stowa i rzeczy. Archeologia nauk humanistycznych. Gdańsk, słowo/obraz terytoria.

Freire P. (2000), ,Bankowa” koncepcja edukacji jako narzędzie opresji. W: K. Blusz (red.), Edukacja $i$ wyzwolenie. Kraków, Oficyna Wydawnicza „Impuls”.

Gadamer H.-G. (2004), Prawda i metoda. Warszawa, Wydawnictwo Naukowe PWN.

Grabowski A., Plato: The Timaeus. W: Internet Encyclopaedia of Philosophy. A Peer-Reviewed Academic Resource. https://iep.utm.edu/timaeus, 26.09.2020.

Hart C. (2011), Force-interactive patterns in immigration discourse: A Cognitive Linguistic approach to CDA. „Discourse \& Society”, 22(3). http://www.jstor.org/stable/42889745, 23.08.2020.

Hart C. (2013), Event-construal in press reports of violence in political protests: A Cognitive Linguistic Approach to CDA. „Journal of Language and Politics”, 12(3).

Klus-Stańska D. (2010), Dydaktyka wobec chaosu pojęć i zdarzeń. Warszawa, Wydawnictwo Akademickie Żak.

Klus-Stańska D. (2019), Paradygmaty dydaktyki. Myśleć teoria o praktyce. Warszawa, Wydawnictwo Naukowe PWN.

Kohlberg L., Mayer R. (1993), Rozwój jako cel wychowania. W: Z. Kwieciński, L. Witkowski (red.), Spory o edukację. Warszawa, IBE.

Kuhn T.S. (2001), Struktura rewolucji naukowych. Warszawa, Aletheia.

Langacker R.W. (1987), Foundations of Cognitive Grammar, vol. 1: Theoretical prerequisites. Stanford, Stanford University Press.

Langacker R.W. (2002), Concept, image, and symbol: The cognitive basis of grammar. Berlin, Mouton de Gruyter.

Męczkowska-Christiansen A. (2014), Citizenship education and its antitheses in the light of knowledge society discourse. W: P. Cunningham, N. Fretwell, Innovative Practice and Research Trends in Identity, Citizenship and Education. London, CiCe.

Męczkowska-Christiansen A. (2015), Nauczyciel we współczesnej rzeczywistości edukacyjnej: menadżer, urzędnik czy obywatel? „Forum Oświatowe”, 27(2).

Niemierko B. (1991), Między ocena szkolna a dydaktyka. Warszawa, WSiP.

OECD (2004), Science and Innovation Policy Key Challenges and Opportunities. www.oecd.org/ science/inno/23706075.pdf, 30.11.2014.

Rancière J. (2007), Dzielenie postrzegalnego. Estetyka i polityka. Kraków, Korporacja Ha!art.

Rutkowiak J. (1992), O dialogu edukacyjnym. Rusztowanie kategorialne. W: idem (red.), Pytanie, dialog, wychowanie. Warszawa, PWN.

Rutkowiak J. (1995a), „Pulsujace kategorie” jako wyznaczniki mapy odmian myślenia o edukacji. W: idem (red.), Odmiany myślenia o edukacji. Kraków, Oficyna Wydawnicza „Impuls”. 
Rutkowiak J. (1995b), Pedagogika ogólna a struktura i jakość wiedzy o wychowaniu. W: T. Hejnicka-Bezwińska (red.), Pedagogika ogólna. Tradycja - teraźniejszość - nowe wyzwania. Bydgoszcz, WSP.

Skarga B. (1989), Granice historyczności. Warszawa, PIW.

Skrzypek E. (2007), Gospodarka oparta na wiedzy i jej wyznaczniki. W: K. Piech, E. Skrzypek (red.), Wiedza w gospodarce, społeczeństwie, przedsiębiorstwach: pomiary, charakterystyka, zarzadzanie. Warszawa, Instytut Wiedzy i Innowacji.

Stownik języka polskiego PWN. https://sjp.pwn.pl, 27.10.2020.

Smith B. (1999), Situatedness/Embeddedness. W: R.A. Wilson, F.C. Keil (eds.), The MIT Encyclopedia of the Cognitive Sciences. Massachusetts, MIT Press.

Talmy L. (2000), Toward a cognitive semantics. Massachusetts, MIT Press.

UNESCO (2005), Towards knowledge societies. UNESCO World Report. Conde-Sur-Noireaue, Imprimerie Corlet.

Watson J.B. (1913), Psychology as the behaviorist views it. „Psychological Review”, 20(2).

Wendland M. (2011), Konstruktywizm komunikacyjny. Poznań, Wydawnictwo Naukowe Instytutu Filozofii Uniwersytetu im. Adama Mickiewicza.

Wittgenstein L. (2002), Tractatus logico-philosophicus. Warszawa, Wydawnictwo Naukowe PWN. Wygotski L.S. (1971), Wybrane prace psychologiczne. Warszawa, PWN.

Zahorodna K. (2015), Problem reprezentacji umystowych $w$ rozszerzonych systemach poznawczych. Wrocław, Wydawnictwo Fundacji „Projekt Nauka”. 